POLIIICAL ECONOM Y RESEARCH INSTIIUTIE

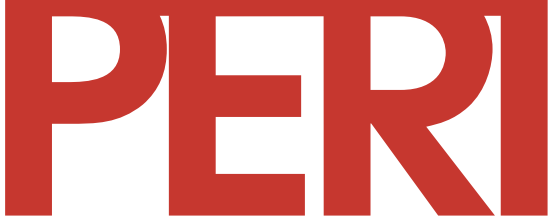

\title{
Let Them Eat Risk? \\ Wealth, Rights, and Disaster Vulnerability
}

\author{
James K. Boyce
}

March 2000

Gordon Hall

418 N Plea sant St., Suite A

Amherst, MA 01002

Telephone: (413) 545-6355 Facsimile: (413) 545-2921

E-mail: peri@eco ns.umass.edu Website:

http:// www.umass.edu/ peri/

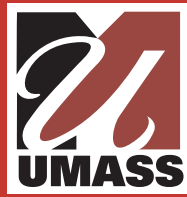




\section{Let Them Eat Risk?}

\section{Wealth, Rights, and Disaster Vulnerability}

James K. Boyce

Department of Economics and

Political Economy Research Institute

University of Massachusetts

Amherst, MA 01003 USA

boyce@econs.umass.edu

March 2000 
Abstract: Disaster-vulnerability reduction is an impure public good: when provided to one it is provided to others, but not equally provided to all. This means that in addition to the question of how much disaster-vulnerability reduction to provide, policy makers face the question of to whom it should be provided. This essay distinguishes between two broad classes of approaches to the latter question, one based on wealth, the other on rights.

Keywords: natural disasters, technological disasters, risk allocation, disaster vulnerability, rights

'We hold these truths to be self-evident, that all men are created equal, that they are endowed by their Creator with certain unalienable Rights, that among these are Life, Liberty and the pursuit of Happiness.'

- United States Declaration of Independence, July 4, 1776

'Every person shall have the right to an environment which is not detrimental to his or her health or well-being.'

- Constitution of the Republic of South Africa, April 27, 1994

\section{Introduction}

Two centuries of history separate the United States Declaration of Independence from the post-apartheid Constitution of the Republic of South Africa, but both documents share the fundamental principle that each person has an equal right to life. This remains a revolutionary idea even today, as we enter the $21^{\text {st }}$ century. 
Bold words do not translate instantly into facts on the ground. More than eight decades elapsed after the Declaration of Independence before the abolition of slavery in the United States. But declarations of principle can define a society's goals, setting a standard by which to judge their subsequent accomplishments.

The idea that every person is endowed with equal rights to life, liberty, the pursuit of happiness, and to a safe and healthy environment, is a universalistic ethical precept. To be sure, it is not universally accepted, let alone universally honored. But this principle has won increasingly widespread acceptance throughout the world, and is today formally incorporated in the constitutions of governments which span the globe (for examples, see the accompanying box).

\section{[INSERT BOX]}

We find a similar trend towards the assertion of an egalitarian right to a safe environment in judicial interpretations of constitutional guarantees. The Supreme Court of India declared in 1991, for example, that the 'right to life' guaranteed in the Indian Constitution 'includes the right to enjoyment of pollution-free water and air for full enjoyment of life'. Similarly, the Supreme Court of Pakistan has ruled that that country's constitutional right to life includes the right to a clean environment; applying this principle, the Pakistani high court ruled that the dumping of nuclear waste in coastal areas of Pakistan would violate the right to life (Popovic, 1996, notes 116 and 117). ${ }^{2}$ 


\section{Public Bads and Public Goods}

Vulnerability to natural and technological disasters is to a large extent a public bad: such disasters typically strike communities, not isolated individuals. By the same token, measures to reduce vulnerability are to a large extent public goods.

Disaster-vulnerability reduction is seldom a pure public good, however, in the strict sense of a good which when provided to one is provided to all (non-excludability), and whose consumption by one does not diminish its availability to others (non-rivalness). The $20^{\text {th }}$ century textbook case of a pure public good was national defense; the $21^{\text {st }}$ century textbook case may be policies to combat global warming.

Many measures to reduce disaster vulnerability are impure public goods, which when provided to one are provided to others, but not equally provided to all. For example, flood-control projects provide location-specific benefits, restricted to the subset of the population who live or own assets in the protected area. Similarly, the reinforcement of public infrastructure against earthquakes primarily benefits its users. Safety measures to prevent or contain the effects of industrial accidents primarily benefit those who live and work nearby. By virtue of where they live, work, or own property, some members of society are excluded from the benefits of these investments. 
Although disaster-vulnerability reduction is not a pure public good, neither is it a pure private good. 'To say a thing is not located at the South Pole,' Paul Samuelson (1955, p. 356) once remarked, 'does not logically place it at the North Pole.' Measures to reduce disaster vulnerability often lie in intermediate terrain between the two (see Figure 1). Some measures, such as cyclone early-warning systems, are near the public end of the spectrum (although some - those with radios, for example - are better able to access this information than others). Others, such as the retrofitting of individual homes in seismic zones, are near the private end of the spectrum. Many are somewhere in between.

\section{[INSERT FIGURE 1]}

This means that in addition to the public policy question of how much disastervulnerability reduction to provide, we must face the question of to whom it should be provided. We face not only the classic economic problem of the allocation of scarce resources among competing ends, but also the classic political-economy problem of the allocation of scarce resources among competing individuals, groups, and classes.

Here I focus on the latter issue. The 'to whom' question is relevant to two key arenas of public policies for risk reduction: first, the allocation of public-sector investment; and second, the creation of an appropriate incentive structure for private-sector investments. In formulating policies in both arenas, two broad classes of approaches to the interpersonal allocation question can be distinguished. For shorthand, I will term them the wealth-based approach and the rights-based approach. 


\section{The Wealth-based Approach}

The wealth-based approach is so widespread among economists that I might be tempted to call it 'the economic approach', but for the fact that there are some economists, myself included, who are not enamoured of it. This approach is founded on willingness to pay, which is conditioned, as always, by ability to pay.

In brief, the wealth-based approach holds that the inter-personal allocation of disastervulnerability reduction should be guided by willingness to pay for those reductions: those individuals who are willing (and, perforce, able) to pay more, deserve to get more. Putting aside inter-personal differences in preferences, including differences in risk aversion, this willingness-to-pay criterion is strongly correlated with wealth. Richer individuals, groups, and classes will get more of the impure public good of disastervulnerability reduction than their poorer counterparts.

Whatever its prescriptive appeal, this principle serves rather well as a first approximation of what often happens in practice: it has considerable descriptive relevance. For example, the casualties from the 1976 earthquake in Guatemala were so unevenly distributed across the population - with most of the 22,000 deaths among the poor - that the disaster was dubbed a 'classquake' (Blaikie et al., 1994, pp. 170-171). The earthquake's disproportionate impact on the poor was due both to the location of their 
homes in landslide-susceptible ravines and gorges, and to their inability to afford earthquake-resistant construction.

Similarly, IFRC Secretary General Didier Cherpitel reminds us that malaria today kills more than one million people each year - the equivalent of a Guatemalan earthquake every eight days - most of them in sub-Saharan Africa. The medical technology to avert many, if not all, of these deaths exists, but it is not effective because 'there is no market in malaria and little buying power in Africa' (Cherpitel, 2000).

The wealth-based approach is not confined to the realm of 'what is'. It also exerts a powerful influence, implicitly or explicitly, on many policymakers' notions of 'what ought to be'. One famous (or infamous) example is the memorandum written by then World Bank chief economist Lawrence Summers in 1992, in which he posed the question, 'Just between you and me, shouldn't the World Bank be encouraging more migration of the dirty industries to the LDCs [less developed countries]?' One reason for such a policy, Summers wrote, was that:

The measurement of the costs of health-impairing pollution depends on the forgone earnings from increased morbidity and mortality. From this point of view a given amount of health-impairing pollution should be done in the country with the lowest cost, which will be the country with the lowest wages. I think the economic logic of dumping a load of toxic waste in the lowest-wage country is impeccable and we should face up to that.$^{3}$ 
Summers' memorandum was noteworthy not so much for the view expressed, but for the fact that it was expressed overtly. One virtue of tactlessness is that it spotlights matters which polite society prefers to leave unmentioned.

\section{Inter-personal Weights in the Measurement of Social Welfare}

Lest we cede the 'economic' terrain to this particular view, we should recall that other economists have advanced alternative notions of social welfare - and hence of development and efficiency - including several economists who, like Summers, have held prominent positions at the World Bank. A quarter century ago, for example, in the landmark volume Redistribution with Growth, Montek Ahluwalia and Hollis Chenery defined the growth of social welfare as a weighted sum of the change in welfare of different subsets of the population:

$$
G=w_{1} g_{1}+w_{2} g_{2}+\ldots+w_{n} g_{n}
$$

where $\mathbf{G}=$ index of growth of total social welfare;

$$
\begin{aligned}
& \mathbf{g}_{\mathbf{i}}=\text { income growth rate of the } \mathrm{i}^{\text {th }} \text { group (e.g., quintiles ranked from poorest to } \\
& \text { richest); }
\end{aligned}
$$


and $\quad \mathbf{w}_{\mathbf{i}}=$ welfare weight assigned to the $\mathrm{i}^{\text {th }} \operatorname{group}\left(\otimes \mathrm{w}_{\mathrm{i}}=1\right)$.

The authors then distinguished three alternative measures. The first equates the weights, $\mathbf{w}_{\mathbf{i}}$, to each group's share in national income. In a 'typical' developing country, for example, Ahluwalia and Chenery noted that the weight of the poorest quintile would be 0.05 , while that of the richest quintile would be 0.53 . In other words, the change in welfare of the richest quintile 'counts' more than ten times more than that of the poorest, reflecting their respective income shares. The resulting index of social welfare is, of course, GNP growth, the conventional measure of economic performance.

Ahluwalia and Chenery's second measure, based on 'equal weights', counts a 1\% gain in income the same whether it is experienced by the poor or the rich. That is, instead of treating each dollar equally, as in the GNP-weights scheme, the equal-weights scheme treats each person (or income class) equally: $\mathbf{w}_{\mathbf{1}}=\mathbf{w}_{\mathbf{2}}=\ldots=\mathbf{w}_{\mathbf{n}}$ for all $\mathrm{i}$ groups.

The third measure is based on 'poverty weights.' These are the opposite of the GNP weighting scheme, in that they put greater weight on gains to the poor than on gains to the rich: $\mathbf{w}_{\mathbf{1}}>\mathbf{w}_{\mathbf{2}}>\ldots>\mathbf{w}_{\mathbf{n}}$. To illustrate, Ahluwalia and Chenery (1974, p. 51) suggest poverty weights of 0.6 on the income change of the poorest $40 \%$ of the population, and 0.1 on that of the richest $20 \%{ }^{4}$

Applying these alternatives social welfare measures to disaster-risk mitigation (instead of to income), we could put equal weight on risk-reductions to all individuals, regardless of 
their income or wealth. Or we could put greater weight on risk reductions for the poorest strata of the population, those who are currently at greatest risk.

\section{The Rights-based Approach}

This brings us back to the rights-based approach. This approach is founded not on the inegalitarian distribution of wealth within and among countries (translated, via real-world markets or the shadow markets of benefit-cost analysis, into willingness to pay), but rather on the egalitarian distribution of the right to a clean and safe environment.

In the allocation of public-sector investments for disaster-risk mitigation, a rights-based approach would assign equal weight to mortality and morbidity impacts across the population, regardless of an individual's wealth or social status. Extending this approach to inter-generational allocation would imply that future lives and health should not be discounted, but rather valued equally with present lives and health.

In shaping private-sector incentives via the legal and regulatory structure, a rights-based approach would define liability on the same basis, with the right to a safe environment held equally by all. Infringements of this right would constitute legal grounds for claims

for restitution. Private firms would seek to insure against such claims, opening an avenue for the insurance sector to play a role in the enforcement of safety standards: the more unsafe the facility, the higher the price of insurance. In the case of industrial disasters, at 
least, this would allow the insurance sector to play a constructive role even when the individuals whose safety is at risk are too poor to buy insurance, for it would be the responsibility of those whose actions jeopardize their safety to insure against any risks to lives and health.

As one who sympathizes with the rights-based approach, I am encouraged by the signs of its growing embrace by peoples and governments around the world. But I want to conclude by noting three tensions which efforts to apply this approach must confront.

First is the problem posed by non-uniform spatial distribution of human populations. There is a difference between saying that each individual has an equal right to risk mitigation and saying that the weight on each individual's risk should be equal. In the latter case, risks in more densely populated areas carry greater weight than the same risks in less densely populated areas, simply because there are more people to add up. Even the most ardent proponents of the former principle - which aims for equality of risk regardless of where people happen to live - probably would not advocate putting a highlevel nuclear waste storage facility in New York City, even if Manhattan island had the same geological properties as Nevada's Yucca Mountain. But the ethical argument that people should not suffer greater disaster risks simply by virtue of living outside great population centers cannot be dismissed lightly.

Second is the problem posed by private risk mitigation. As an impure public good, disaster-risk mitigation has some components which can be privately purchased, the 
distribution of which is founded on ability and willingness to pay - for example, living in more earthquake-resistant homes. This fact provides compelling grounds for public policies which put priority on risk mitigation for those who are less able to obtain it privately - a disaster-vulnerability application of Ahluwalia and Chenery's poverty weights.

Finally, we must face the tensions between an egalitarian allocation of the right to life (and hence to disaster-vulnerability reduction) and the inegalitarian allocation of economic wealth and political power. Lawrence Summers alluded to this problem in his memorandum:

The problem with the arguments against all of these proposals for more pollution in LDCs (intrinsic rights to certain goods, moral reasons, social concerns, lack of adequate markets, etc.) could be turned around and used more or less effectively against every Bank proposal for liberalization.

This is, perhaps, an exaggeration. Wealth-based and rights-based approaches to interpersonal allocations have long co-existed, and tensions between them will remain a feature of modern societies for the foreseeable future. Nevertheless, the sphere of the rights-based approach has gradually widened over time. The abolition of slavery is one example; the extension of the right to vote to all adult citizens, instead of its restriction on the basis of property ownership, race, or gender, is another; the advent and spread of free 
public education is a third. The rights-based approach to disaster vulnerability represents a further step on this road.

The radically egalitarian principles proclaimed in the US Declaration of Independence and the South African constitution were, and remain today, actively contested. Yet these principles are on the ascendancy worldwide. As my late countryman, Dr. Martin Luther King, Jr., once remarked, 'The moral arc of history is long, but it bends toward justice.'

There is no magic recipe for pursuing a rights-based approach to disaster-vulnerability reduction in the face of the predictable opposition from vested interests who favor a wealth-based approach. But those who accept the challenges of moving in this direction can take heart from the belief that history is on their side.

\section{Acknowledgement}

This paper is based on remarks at the ProVention Consortium Conference on Reducing Disasters through Development, Washington, D.C., 2-4 February 2000. I am grateful to the conference participants for their thoughts and comments. 


\section{Notes}

${ }^{1}$ Subash Kumar v. State of Bihar, 1991 A.I.R. 420, 424 (India Sup. Ct. 1991), cited by Popovic (1996, note 118). For discussion, see also Anderson (1996).

${ }^{2}$ For discussion, see also Lau (1996).

3 This statement appears in an excerpt from the memorandum published in The Economist (1992) under the title 'Let them eat pollution.'

4 Benefit-cost analysis similarly can incorporate distributional weights which value dollars differently depending on to whom they accrue. For discussions, see Little and Mirrlees (1974, pp. 234-242) and Ray (1984, pp. 22-31). 


\section{References}

Ahluwalia, M.S. and H. Chenery (1974) 'The Economic Framework.' In H. Chenery et al., Redistribution with Growth. Oxford University Press, Oxford: 38-51.

Anderson, M.R. (1996) 'Individual Rights to Environmental Protection in India,' in A.E. Boyle and M.R. Anderson, eds., Human Rights Approaches to Environmental Protection. Clarendon, Oxford: 199-225.

Blaikie, P., T. Cannon, I. Davis and B. Wisner (1994) At Risk: Natural Hazards, People's Vulnerability, and Disasters. Routledge, London.

Cherpitel, D.J. (2000) 'The Changing Nature of Disaster Response and Recovery in the $21^{\text {st }}$ Century,' Statement to the ProVention Consortium Conference on Reducing Disasters through Development, Washington, D.C., 2-4 February. International Federation of Red Cross and Red Crescent Societies, Geneva.

Economist (1992) 'Let them eat pollution.' 8 February, p. 66.

Lau, M. (1996) 'Islam and Judicial Activism: Public Interest Litigation and Environmental Protection in the Islamic Republic of Pakistan,' in A.E. Boyle and M.R. 
Anderson, eds., Human Rights Approaches to Environmental Protection. Clarendon, Oxford: 285-302.

Little, I.M.D. and J. Mirrlees (1974) Project Appraisal and Planning for Developing Countries. Basic Books, New York.

Popovic, N.A.F. (1996) 'In Pursuit of Environmental Human Rights', Columbia Human Rights Law Review 27(487).

Ray, A. (1984) Cost-Benefit Analysis: Issues and Methodologies. Published for the World Bank by the Johns Hopkins University Press, Baltimore.

Samuelson, P. (1955) 'Diagrammatic Exposition of a Theory of Public Expenditure,' Review of Economics and Statistics 37(4): 350-356. 


\section{Box: Examples of Constitutional Rights to the Environment}

'All residents enjoy the right to a healthy, balanced environment.'

- Argentina Constitution, art. 41

'Every person shall have the right to a wholesome environment.'

- Belarus Constitution, art. 46

'Every person has the right to a healthy, satisfying and lasting environment.'

- Benin Constitution, art. 27

'Citizens have the right to a healthy and favorable environment.'

- Bulgaria Constitution, art. 55

'The right to a healthy environment shall be recognized.'

- Burkina Faso Constitution, art. 31

'The Constitution guarantees to all persons: . . . The right to live in an environment free from contamination.'

- Chile Constitution (1980), Ch. III, art. 19(8)

'Every individual has the right to enjoy a healthy environment.'

- Colombia Constitution, art. 79

'All persons have the right to a clean and healthy environment.'

- Ethiopia Constitution, art. 44(1)

'All citizens shall have the right to a healthy and pleasant environment.'

- Korea Constitution, Ch. II, art. 35 (1987)

'Citizens of the Kyrghyz Republic shall have the right to a healthy safe environment.'

- Kyrghyz Constitution, art. 35

'Every human being has the right to live an environment that is ecologically safe for life and health.'

- Moldova Constitution, art. 37

'Everyone shall have the right to a healthy and ecologically balanced human environment and the duty to defend it.'

- Portugal Constitution, pt. I, 1 III, ch. II, art. 66(1) (1982)

'Everyone has the right to live in a healthy, balanced environment.'

- Turkey Constitution, ch. VIII(A), art. 56 (1982)

Source: Neil A. F. Popovic, 'In Pursuit of Environmental Human Rights: Commentary on the Draft Declaration of Principles on Human Rights and the Environment,' Columbia Human Rights Law Review, Vol. 27, Spring 1996. 
Figure 1: Disaster Vulnerability as an Impure Public Bad

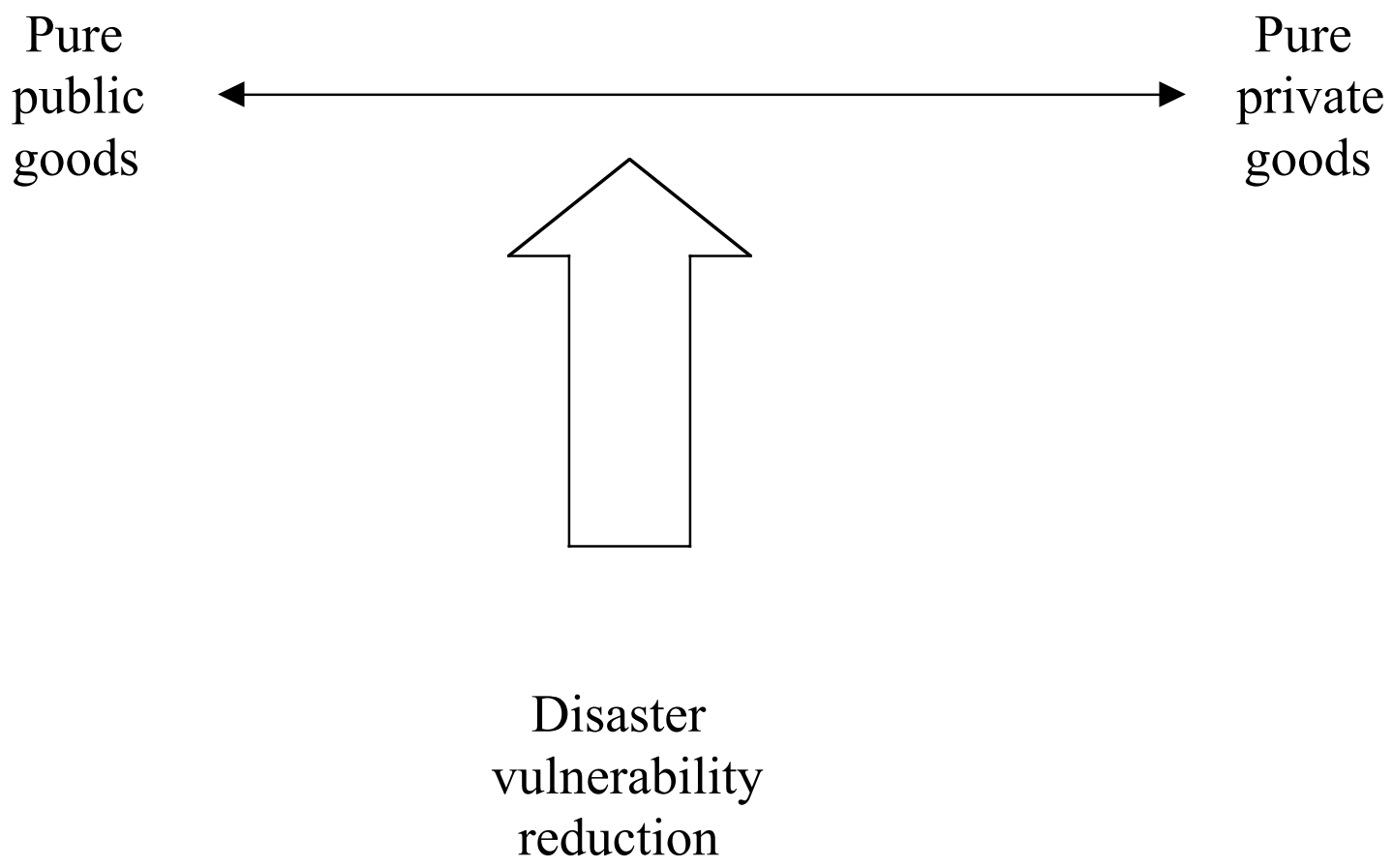

